\title{
A Projection Approach of Tourist Circulation under Conditions of Uncertainty
}

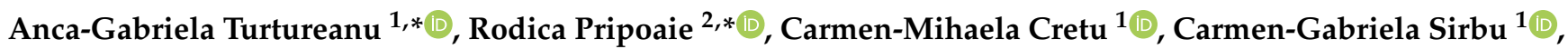 \\ Emanuel Ştefan Marinescu ${ }^{3}$, Laurentiu-Gabriel Talaghir ${ }^{4,5}$ and Florentina Chițu ${ }^{6} \mathbb{C}$
}

check for

updates

Citation: Turtureanu, A.-G.; Pripoaie,

R.; Cretu, C.-M.; Sirbu, C.-G.;

Marinescu, E.Ş.; Talaghir, L.-G.;

Chițu, F. A Projection Approach of

Tourist Circulation under Conditions

of Uncertainty. Sustainability 2022, 14,

1964. https://doi.org/10.3390/

su14041964

Academic Editors: Alina Badulescu

and Vicky Katsoni

Received: 16 December 2021

Accepted: 1 February 2022

Published: 9 February 2022

Publisher's Note: MDPI stays neutral with regard to jurisdictional claims in published maps and institutional affiliations.

Copyright: () 2022 by the authors Licensee MDPI, Basel, Switzerland. This article is an open access article distributed under the terms and conditions of the Creative Commons Attribution (CC BY) license (https:// creativecommons.org/licenses/by/ $4.0 /)$.
1 Faculty of Economic Sciences, Danubius University of Galati, 800654 Galati, Romania; carmencretu@univ-danubius.ro (C.-M.C.); carmensirbu@univ-danubius.ro (C.-G.S.)

2 Faculty of Law and Administrative Sciences, "Dunărea de Jos" University of Galati, 800008 Galati, Romania

3 Faculty of Communication and International Relations, Danubius University of Galati, 800654 Galati, Romania; marinescuemanuel@univ-danubius.ro

4 Faculty of Physical Education and Sport, Dunarea de Jos University of Galati, 800008 Galati, Romania; gabriel.Talaghir@ugal.ro

5 Institute of Sport, Tourism and Service, South Ural State University, 454080 Chelyabinsk, Russia

6 The Economics and International Business Doctoral School, Bucharest University of Economic Studies, 010374 Bucharest, Romania; florentina.chitu@stud.ase.ro

* Correspondence: ancaturtureanu@univ-danubius.ro (A.-G.T.); rodica.pripoaie@ugal.ro (R.P.)

\begin{abstract}
This paper explores an important problem in tourism demand analysis, namely, the inherent uncertainty involved in projecting tourism demand. Tourism demand continues to be severely affected by unforeseen events associated with the current global health crisis, which has led to an examination of ways to predict the devastating effects of the COVID-19 pandemic on tourism. Tourism flow forecasting relating to arrivals is of particular importance for tourism and the entire hospitality industry, because it is an indicator of future demand. Thus, it provides fundamental information that can be applied in the planning and development of future strategies. Accurate forecasts of seasonal tourist flows can help decision-makers increase the efficiency of their strategic planning and reduce the risk of decision-making failure. Due to the growing interest in more advanced forecasting methods, we applied the ARMA model method to analyze the evolution of monthly arrival series for Romania in the period from January 2010 to September 2021, in order to ascertain the best statistical forecasting model for arrivals. We conducted this research to find the best method of forecasting tourist demand, and we compared two forecasting models: AR(1)MA(1) and $\operatorname{AR}(1) M A(2)$. Our study results show that the superior model for the prediction of tourist demand is $\operatorname{AR}(1) M A(1)$.
\end{abstract}

Keywords: projection tourist flow; innovation; AR(1)MA(1); health crisis; seasonality

\section{Introduction}

The coronavirus pandemic has turned the world upside down since the second quarter of 2020. The first sectors to be severely impacted by the coronavirus crisis were transport, tourism, and hospitality, as well as the event planning industry. There is no doubt that the tourism industry's status quo has been severely impacted by the pandemic. The latest annual WTTC [1] research shows that tourism suffered a loss of almost 5 trillion dollars in 2020, with the contribution to GDP falling by a staggering $49.1 \%$ compared with 2019 . In 2020, 62 million jobs were lost, and domestic visitor spending fell by $45 \%$ [2], while spending by international visitors fell by an unprecedented $69.4 \%$.

There have been other crisis situations that have had a detrimental impact on tourism, including the financial crisis of 2008-2010, various international terrorism events [3], including the fall of the twin towers in the United States of America in 2001, bankruptcies in tourism, and natural disasters, such as the 2021 volcanic eruption in Spain that disrupted 
a considerable number of European flights. However, these different crises did not have such a devastating impact on travel as the current pandemic, because they were not global events [4]. In the case of COVID-19, once social distancing policies were implemented, there was a significant decrease in tourist arrivals, which reduced the total travel expense income at the point of destination. Tourism seems to be particularly vulnerable to health crises [5], because policies apply [6] to prevent the spread of contagions, such as restrictions on mobility and social distancing. These restrictions negatively affect most tourism-related services by impeding movement [7] between regions or countries and changing travel motivations, which produces supply shocks [8].

The forecasting of tourist activity in a pandemic is also hampered by the fact that tourism depends upon direct contact being established at the moment of consumption. Unlike the market for goods, in the purchase of a tourism product [9], the consumer is faced with a series of uncertainties and much greater risks, which only arise during tourist consumption.

Any attempt to forecast tourism activity must consider two essential variables in tourist circulation, namely, seasonality and motivation. Tourist motivation includes needs, impulses, intentions, values, and specific tendencies, all of which have a personal feature. The motivation (vocation, inclination) generate tourist demand, which is always quite personal and subjective, and it is determined by psychological impulses [10] and exogenous factors (environmental influences) [11]. Thus, during the current pandemic, the uncertainty and risk to which a traveler is exposed causes their motivation to travel to decrease in intensity, which influences the dynamics of travel [12]. The changes in tourism motivation are a balance between necessity and satisfaction, with the balance tipping in favor of the latter. On the one hand, satisfaction is one of the most important stimuli of international tourist traffic, whereas necessity tends to stimulate domestic tourist traffic. The basis for transforming tourist demand into consumption is mainly the motivation to travel. Tourist motivation is seen as a stimulating element of tourist traffic. There is an intrinsic link between motivation and tourist traffic, which is why in the absence of tourist motivation, any attempt to estimate passenger flows would be difficult to achieve and it would not be of practical applicability.

Given the current situation in Romania, which is still at the peak of the fourth wave of COVID-19 infections, we can say that in terms of both real risks and the emotional component, there will be a prolonged period in which we will see limited consumption of nonessential goods, a slowdown in activity in sectors where physical presence is required [13], and a lower attractiveness of domestic and international travel and tourism packages.

One of the key differences of the tourism industry from other economic sectors is that, although health hazards do not destroy the infrastructure, they affect the flow [9] of tourists. The emphasis of this paper is the ability and power to estimate tourist flow in the current, uncertain conditions.

For central authorities, but also for economic agents that are active in the field of tourism, the foreknowledge of a possible trend in the number of tourist arrivals is especially important for establishing a medium- to long-term strategy, depending on the risk and uncertainty of the conditions. Additionally, the possibility of estimating the flow of tourists is particularly useful for anticipating the necessary labor force in the field of tourism and HORECA, which are facing acute staff shortages in Romania. Estimating tourist arrivals allows for the hiring of immigrant workers as necessary.

The research presented in this paper has theoretical applicability, by establishing a forecast model of tourist flow in Romania in the context of the current pandemic, as well as in practice, through offering the possibility of anticipating tourist flow, according to which the Romanian decision-making bodies can establish the necessary measures to mitigate the negative effects of the pandemic upon Romanian tourism. 


\section{Literature Review}

The literature review was approached in this study from two perspectives. On the one hand, some of the literature reflected the impact of the pandemic crisis caused by the SARS-CoV-2 virus on the entire tourism industry, and on the other hand, we reviewed the specialized literature on forecasting tourism.

\subsection{The Impact of the COVID-19 Health Crisis on the Tourism Industry}

The tourism sector is currently facing difficult times, as it is one of the most affected by the effects of the global pandemic [14].

At the structural changes that are taking place at the social level and that affect [15], among many other aspects, the way we work, consume and travel, there is a growing trend towards sustainability $[16,17]$ — prior to the situation caused by COVID-19-which foreshadows that we are part of a fundamental transition in the vast majority of sectors [18].

The HORECA sector, as a very important part of the tourism sector, is no stranger to this [19], or to the need for a new management model that respects the environment and the limits of the planet, as it wishes to ensure the continuity of its activity [20,21].

The positive results obtained in 2019 have prepared the players in the field for a favorable evolution in 2020 [22]. However, the traffic restrictions imposed during the state of emergency, some of which have been maintained and are on alert, have seriously affected the performance of this sector [23].

Humanity is going through a period in which the pace of change [24] is accelerating, with more and more aspects of the future being characterized by high levels of risk and uncertainty [25]. As a result, the future no longer flows linearly from the past and the present; the discontinuities are multiplying [26], which makes forecasting activity absolutely necessary [27].

The actions are oriented towards excellence for the future [28], which is why specialists from all over the world who undertake them are good and fine connoisseurs of forecasting methods [29], procedures and techniques [30].

Given the high degree of uncertainty that the future holds, the hypotheses acquire an increasingly important role in the forecasts of the tourism industry [31].

Predictive studies in the field of tourism are all the more necessary [32] as the share of tourism activities in all activities carried out at the level of a national economy become higher, the more the dynamics of changes in the field of tourism increases, the more ephemeral the market is and its fluctuations in demand, and the more unstable customers' behavior becomes in the face of the global challenges posed by the COVID-19 pandemic [33].

In general, there is a consensus on the importance of the forecasting and planning of activity in the tourism industry. Travel demand forecasting is essential in creating a rapid response to a variety of unexpected and unpredictable situations [34] that arise in this activity in the current conditions of uncertainty $[35,36]$.

Tourist flows in most destinations vary seasonally [37]. Seasonality is one of the most important and distinctive features of tourism demand and has an important impact on the planning and operation of tourism business and on destination management $[38,39]$ in terms of infrastructure and resource allocation [40].

The tourist demand usually presents as seasonal models [41]. One of the main characteristics of the tourist product is the existence of seasonal oscillations in the demand and implicitly of the production of the tourist services [42]. These seasonal fluctuations are characterized by a high degree of tourist flows in certain periods of the calendar year and by a significant reduction in them or even a halt in tourist arrivals [43].

Seasonality has direct consequences [44] both on the development of tourism and on other branches of the national economy whose evolution is related to the development of tourism [45]. The consequences of the seasonality of the tourist product demand [46] determine either the incomplete use of the material base and the labor force with negative effects on the possibility of recovering the expenses (in the periods with reduced demand (pre-, post- and off-season), or of the accommodation, food and other categories of spaces 
that ensure the provision of tourist services as well as the service staff, which influence the quality of the services offered, and could cause dissatisfaction to tourists [47].

Seasonal fluctuations are affected by a number of factors either relatively constant [48] or by a number of other conjunctural factors such as crises (economic, health, etc.). Forecasts play [48] a major role in tourism planning; they are even more valuable in times of crisis and post-crisis $[49,50]$.

However, "tourism demand" is a broad concept that is not easy to measure by a certain standard [51]. Tourism demand could be measured by the number of tourist arrivals, tourist expenses or the number of nights spent by tourists [52]. The number of tourist arrivals has been widely used as an adequate indicator of tourism demand [53] because the collection of data on timely tourist expenditures is complex and very difficult [54]. In the present research, we have considered the prediction of tourist demand expressed by the number of arrivals. In Romania, in addition to arrivals registered by the tourism industry, we also find non-tourist arrivals such as those of migrants who transit the country for working in western Europe or nationals who return from work in other countries for various events and mostly do not use the structures classified as tourist reception with tourist accommodation functions.

Tourism demand is the basis on which all business tourism decisions ultimately depend [55]. Accurate estimations of tourism demand are essential for the tourism industry, because they can help reduce risk and uncertainty [56], as well as provide effective background information for better tourism planning [57].

\subsection{Specialized Literature That Addresses the Subject of Tourism Prediction}

The main purpose of the industry forecast is to identify significant patterns of change and to develop hypotheses about the most likely dynamics rates of various segments of the hospitality industry.

The tourism industry experienced a real boom until 2019, many destinations experienced a remarkable development [57] with a growth rate that varied unevenly each year, but with constant growth for some destinations, but there were also cases when - there were decreases in the tourist flow [58]. For such an evolution, precise forecasts of tourism demand are needed.

The literature on tourism modeling and forecasting has developed a lot in the last four decades $[59,60]$. In-depth studies have been conducted by both qualitative and quantitative methods [61,62]. Qualitative methods of tourism forecasting [63] explore the changes that a certain state of affairs of maximum interest will undergo, in the medium or long term, based both on the evolution of past data [64] and considering a number of causal factors [65,66] and inter-correlation [67]. Quantitative methods aim at estimating the evolution of quantitative indicators in a short period of time [68], based on the future extrapolation of existing data at a given time $[69,70]$.

Due to the fluctuation and complexity of the tourism industry, the prediction methods must capture even the finest nuances of non-stationary property and accurately describe its evolutionary trend. Some authors have used machine learning methods [71-74] or neural networks to predict tourism demand more accurately [40,67,75-79].

The continuous increase in tourism demand highlights the importance of correctly anticipating the number of arrivals at the destination. Improving tourism demand forecasts has led to a large body of research for times of crisis generated by economic [80,81], social [82], terrorism [83] or health factors [69].

This paper uses statistical and econometric methods to determine the most accurate prediction of tourism demand expressed by arrivals [84] in the classic conditions of seasonality [85], under conditions of uncertainty created by COVID-19 pandemic that influences all activities [86]. 


\section{Materials and Methods}

Given the fact that the tourist activity has a seasonal feature, and the series chosen to study the flow of tourists, i.e., the arrivals in Romania proved to be unstable by applying the ADF (augmented Dickey-Fuller) and PP (Phillips-Perron) stationarity tests, but also auto-correlation function graph (ACF) and partial auto-correlation function graph (PACF), we have applied the ARMA method. The result was two possible ARMA models according to the ACF and PACF correlogram for the initial series that was stationary by logarithm. Thus, the ARMA models identified as being possible depending on the lags that exceed the confidence band for autocorrelation and partial correlation were AR(1)MA(1) and $\mathrm{AR}(1) \mathrm{MA}(2)$, and by their comparative analysis, we obtained the AR(1)MA(1) model which can be used to forecast the tourist flow in Romania. This model turned out to be a stationary and parsimonious model that fits the data well. The model selection criteria were: significance of the ARMA components, and comparisons of Akaike, Schwartz and Hannan-Quinn, and Durbin-Watson statistics. Thus, the chosen model AR(1)MA(1) meets the requirements for a stable univariate process and it accurately describes the previous evolution of the series of arrivals.

Knowing that an ARMA analysis is more of an art than a science, because there is no perfect model or true model, it will only be chosen the forecast model if the specialist considers that it meets the absolutely necessary requirements. Thus, the model found by the automatic application of the methods offered by machine learning must be completed with an analysis assisted by the researcher who may or may not confirm the chosen model automatically. In our study, we checked which model is automatically chosen by the software EViews, and it turned out that it coincides with that we found by going through the entire econometric methodology, namely, the AR(1)MA(1) model.

\subsection{Study Description and Dataset}

This study considers monthly data arrivals in Romania (arr series), in the period January 2010-September 2021. The statistical data were obtained from the official website of the National Institute of Statistics Romania (www.insse.ro accessed on 5 December 2021).

The COVID-19 pandemic has impacted a number of economic sectors, one of the most affected of which has been tourism. The causes that generated the sharp reduction in the tourism sector in Romania in the post-pandemic period are numerous, as shown in Figure 1.



Figure 1. The causes of the reduction in tourism in Romania in the post-pandemic period.

As a result of the reduction in both domestic and international tourist arrivals in Romania, and implicitly, of the reduced revenues obtained from tourism, it is particularly important for both tour operators and government institutions to forecast the future, shortmedium-term evolution of tourist arrivals in order to estimate the future income that can be obtained from this sector. For this purpose, forecasting arrivals in Romania in the next 
period, we will look for the best model that can statistically approximate the evolution of this series of monthly data.

\subsection{The Algorithm of the Forecast System of Arrivals in Romania in the Post-Pandemic Period}

In order to choose a forecast model for arrivals, we followed the following algorithm for this study based on the methodology mentioned in Figure 2.

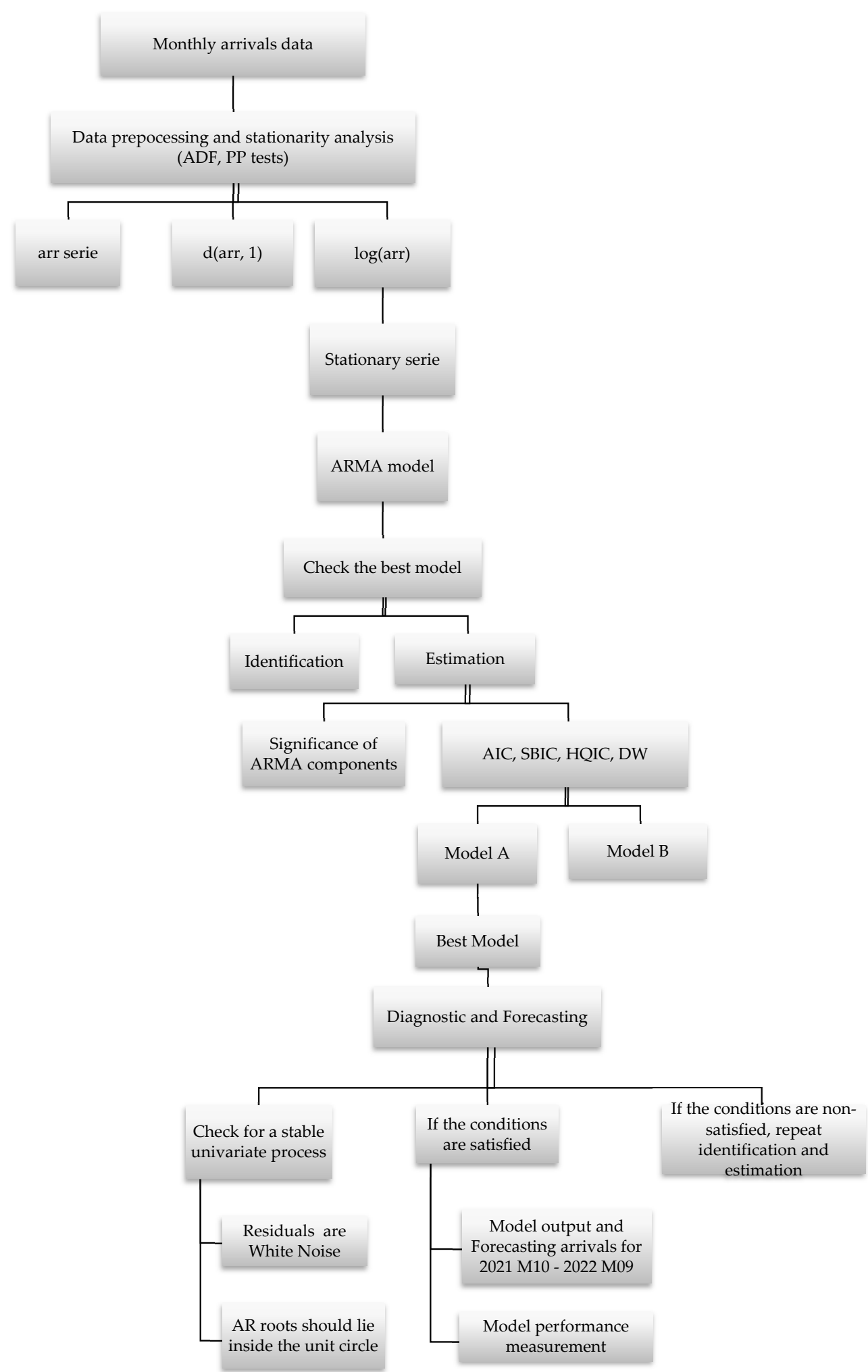

Figure 2. The algorithm of the forecast system for arrivals in Romania in the post-pandemic period. 
The evolution of the monthly series of arrivals for Romania between January 2010 and September 2021, based on statistical data obtained from the National Institute of Statistics of Romania, www.insse.ro (accessed on 1 December 2021), is plotted in Figure 3.

Arrivals

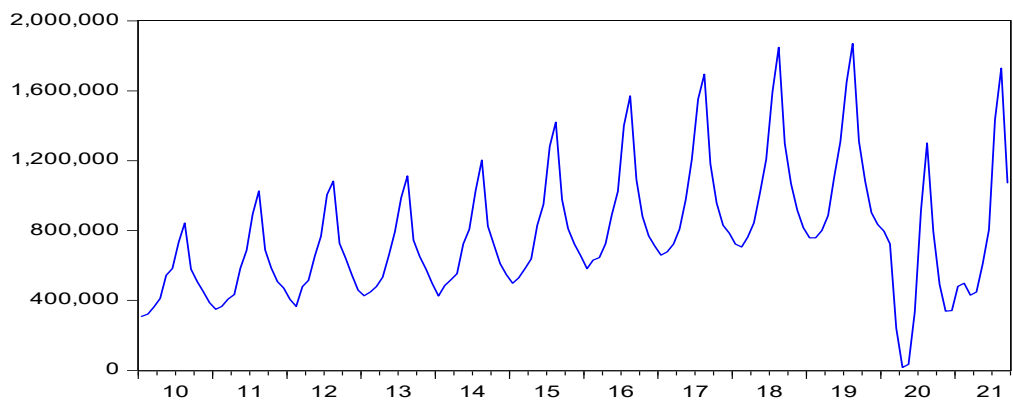

Figure 3. Evolution of arrivals in Romania in the period 2010-2021.

In order to choose a statistical forecast model for arrivals in Romania, it must meet certain conditions, which is why we started by studying the normality and stationarity of the arr series, according to Table 1.

Table 1. Descriptive statistics for arrivals in Romania.

\begin{tabular}{cc}
\hline Indicators & Arrivals \\
\hline Mean & $779,086.0$ \\
Median & $723,934.0$ \\
Maximum & $1,869,383$ \\
Minimum & $16,855.00$ \\
Std. Dev. & $357,065.4$ \\
Skewness & 0.894571 \\
Kurtosis & 3.745785 \\
\hline Jarque-Bera & 22.07369 \\
Probability & 0.000016 \\
\hline Sum & $1.10 \times 10^{8}$ \\
Sum Sq. Dev. & $1.78 \times 10^{13}$ \\
\hline Observations & 141 \\
\hline
\end{tabular}

Verifying the stationarity of the initial series arr and the series $d$ (arr, 1) was performed using the auto-correlation function graph [87] (ACF), partial auto-correlation function graph [88] (PACF), as well as through the ADF [89] test (augmented Dickey-Fuller) and PP [90] (Phillips-Perron), and it was found that both series studied were not stationary. For this reason, we studied the stationarity of the $\log ($ arr $)$ series obtained by logarithmizing the initial series arr, which proved to be stationary according to the ADF and PP tests, which allowed us to apply an ARMA model $(p, q)$.

The ARMA model attributed to Box-Jenkins (1970) can be applied in tourism forecasting for monthly number of tourist arrivals. The ARMA model used the order of the autoregressive (AR) model $(p)$ and the order of the moving average (MA) model $(q)$, called ARMA by the Box-Jenkin models $(p, q)$.

"An ARMA based model has a significant advantage in terms of forecast accuracy. This magnitude of improvement in the accuracy of the model is likely to have a considerable positive effect on the quality of various managerial decisions made by hospitality industries and recreation manager" [40].

ARMA is "an algorithm for the covariance determinant of a stationary autoregressivemoving average model is considered. Some asymptotic properties of this determinant in the stationarity and invertibility region of the process are studied numerically" [91]. 
Given that tourism activity is seasonal (Figure 4) in general, and that the logarithmic series is stationary, the Box and Jenkins test can be applied.

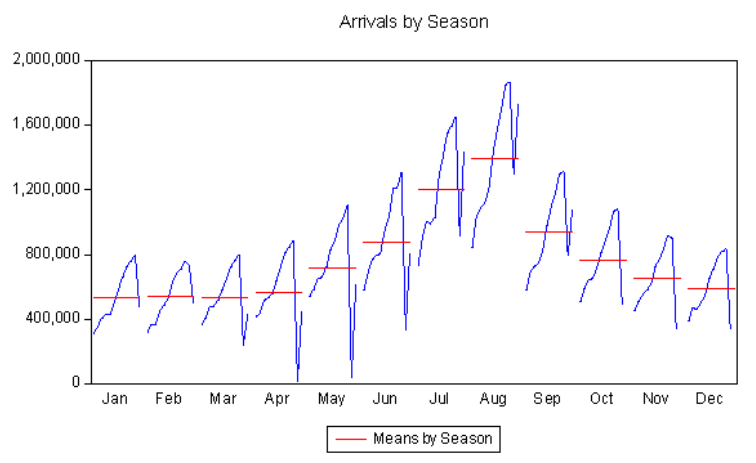

Figure 4. Evolution of arrivals in Romania by season.

\subsection{Methodology}

The Box and Jenkins test (1970) for choosing a model for determining the prediction model involves three steps, namely: Identification, Estimation, and Diagnosis and Forecasting.

\subsubsection{Identification}

An ARMA model $(p, q)$ is linear, and is obtained as a linear combination of two other linear models.

Based on the output of the ADF test, it is found that the probability associated with the constant $c$ is 0.002 , being less than the critical value 0.05 , which means that this constant $c$ must be included in the ARMA model.

Thus, for the stationary function $\log ($ arr $)$, we can write:

$$
\log (\text { arr })_{t}=c+\sum_{i=1}^{p} \alpha * \log (\text { arr })_{t-1}+\sum_{j=1}^{q} \theta * E_{t-j}+E_{t}
$$

Based on the ACF and PACF correlogram for the log (arr) series, possible ARMA models are identified based on the lags that exceed the confidence bands for autocorrelation and partial correlation. Thus, it is found that the possible models are AR(1)MA(1) and $\operatorname{AR}(1) \mathrm{MA}(2)$.

\subsubsection{Estimation of Models}

We tested the possible ARMA models, i.e., $\mathrm{AR}(1) \mathrm{MA}(1)$ and $\mathrm{AR}(1) \mathrm{MA}(2)$, to find a stationary and parsimonious model that fitted the data well. The model selection criteria were:

- $\quad$ Significance of the ARMA components;

- Comparing Akaike, Schwartz and Hannan-Quinn, and the smaller is better;

- Comparing Durbin-Watson statistics, with a value closer to two being better.

Based on these criteria, it is found that the AR(1)MA(1) is the model that could be used to forecast the arrival of tourists from Romania.

\subsubsection{Diagnosis and Forecasting}

The requirements for a stable univariate process are:

- Residuals of the model are white noise applied Ljung-Box Q statistic;

- Null hypothesis: residuals are white noise;

- Check if the estimated ARMA process is (covariance) stationary: AR roots should lie inside the unit circle;

- Check if the estimated ARMA process is invertible: all MA roots should lie inside the unit circle. 
If the conditions are satisfied, we can forecast with this model and if the conditions are not satisfied, we need to repeat the selection and estimation method.

On $\operatorname{AR}(1) M A(1)$ all these conditions are met so we can move on to the next step, respectively we can forecast with this model $\mathrm{AR}(1) \mathrm{MA}(1)$.

Additionally, if we proceeded with the automatic analysis of the forecast with ARMA model using the statistical program EViews, the whole model AR(1)MA(1) is determined automatically.

\subsubsection{Forecast with the Chosen Model and Comparison with Statistical Data}

Finally, the historical data for arrivals were compared with the forecast values from ARMA $(1,1)$ which revealed a very good approximation. In conclusion, it can be chosen as forecast model for arrivals in Romania in the conditions of uncertainty generated by the COVID-19 pandemic is the ARMA model $(1,1)$.

\section{Results}

\subsection{Stationary Verification}

To verify the stationarity of the series, we applied the ADF (augmented Dickey-Fuller) and PP (Phillips-Perron) stationarity tests, and we obtained the following results which showed us that the arr and $d(a r r, 1)$ series are not stationary, whereas the $\log (\operatorname{arr})$ series is stationary. (Table 2). Starting from $\mathrm{H}_{0}$ (null hypothesis): $\operatorname{arr} / \mathrm{d}$ (arr)/log (arr) has a unit root; applying ADF and PP using EViews resulted in the following values in Table 2.

Table 2. ADF and PP tests for arrivals series.

\begin{tabular}{|c|c|c|c|c|}
\hline Serie & & & $\mathrm{t}$-Statistic & Prob. * \\
\hline \multirow[t]{4}{*}{ arr } & \multicolumn{2}{|c|}{ Augmented Dickey-Fuller test statistic } & -1.951925 & 0.3078 \\
\hline & Test critical values: & $1 \%$ level & -3.482453 & \\
\hline & & $5 \%$ level & -2.884291 & \\
\hline & & $10 \%$ level & -2.578981 & \\
\hline \multirow[t]{4}{*}{ arr } & \multicolumn{2}{|l|}{ Phillips-Perron test statistic } & -3.055846 & 0.1212 \\
\hline & Test critical values: & $1 \%$ level & -4.024935 & \\
\hline & & $5 \%$ level & -3.442238 & \\
\hline & & $10 \%$ level & -3.145744 & \\
\hline \multirow[t]{4}{*}{$d(a r r, 1)$} & Augmented Dickey-Fuller test statistic & & -3.782047 & 0.0206 \\
\hline & Test critical values: & $1 \%$ level & -4.031899 & \\
\hline & & $5 \%$ level & -3.445590 & \\
\hline & & $10 \%$ level & -3.147710 & \\
\hline \multirow[t]{4}{*}{$d(a r r, 1)$} & Phillips-Perron test statistic & & -3.981783 & 0.0188 \\
\hline & Test critical values: & $1 \%$ level & -4.025426 & \\
\hline & & $5 \%$ level & -3.442474 & \\
\hline & & $10 \%$ level & -3.145882 & \\
\hline \multirow[t]{4}{*}{$\log (\operatorname{arr})$} & Augmented Dickey-Fuller test statistic & & -4.872991 & 0.0006 \\
\hline & Test critical values: & $1 \%$ level & -4.025924 & \\
\hline & & $5 \%$ level & -3.442712 & \\
\hline & & $10 \%$ level & -3.146022 & \\
\hline \multirow[t]{4}{*}{$\log (a r r)$} & Phillips-Perron test statistic & & -3.587904 & 0.0072 \\
\hline & Test critical values: & $1 \%$ level & -3.477487 & \\
\hline & & $5 \%$ level & -2.882127 & \\
\hline & & $10 \%$ level & -2.577827 & \\
\hline
\end{tabular}

* MacKinnon (1996) one-sided p-values.

Based on the results obtained by processing the series using the statistical software EViews for the centralized ADF and PP tests in Table 2, for the series arr and $d$ (arr, 1), $\mathrm{H}_{0}$ cannot be rejected because the value of the test is higher than the critical value; thus, the series have a unitary root and they are non-stationary, for a relevance level of $1 \%$. The same result is obtained if we analyze the probability associated with ADF and PP tests which is 
higher than the lowest level of relevance, namely, 0.01. Therefore, it can be stated that the hypothesis $\mathrm{H}_{0}$ is accepted and that the series arr and $d(\operatorname{arr}, 1)$ have a unitary root; therefore, it can be stated that these series are non-stationary.

For the $\log (\mathrm{arr})$ series, $\mathrm{H}_{0}$ is accepted because the value of the statistical test is less than the critical value, for a relevance level of $1 \%$. Therefore, we will choose the $\log$ (arr) series because it is stationary and does not require differentiation, unlike the initial arrivals series which is not stationary even after the difference of order 1 . Thus, we can say that the $\log ($ arr $)$ series is stationary, and that an ARMA model $(p, q)$ can be applied because it does not need differentiation. Given that the probability corresponds to the $c$ constant in the ADF test, which is $0<0.05$, we will include the $c$ constant in the ARMA model. Additionally, for the $\log$ (arr) series the Durbin-Watson coefficient has a value of 1.927879 which is close to 2 , which means that the parameters are stable, according to Table 3.

Table 3. Output for ADF test $\log$ (arr) series.

\begin{tabular}{ccccc}
\hline Variable & Coefficient & Std. Error & t-Statistic & Prob. \\
\hline L_ARRIVALS(-1) & -0.268666 & 0.055134 & -4.872991 & 0.0000 \\
D(L_ARRIVALS(-1)) & 0.620091 & 0.072046 & 8.606876 & 0.0000 \\
D(L_ARRIVALS(-2)) & -0.249911 & 0.084399 & -2.961081 & 0.0036 \\
C & 3.584175 & 0.734571 & 4.879274 & 0.0000 \\
@TREND(“2010M01”) & 0.000451 & 0.000644 & 0.699368 & 0.4855 \\
\hline R-squared & 0.433407 & Mean dependent var & 0.007848 \\
Adjusted R-squared & 0.416367 & S.D. dependent var & 0.388562 \\
S.E. of regression & 0.296846 & Akaike information criterion & 0.444351 \\
Sum squared residual & 11.71961 & Schwarz criterion & 0.550411 \\
Log likelihood & -25.66022 & Hannan-Quinn criterion & 0.487451 \\
F-statistic & 25.43409 & Durbin-Watson stat & 1.927879 \\
Prob(F-statistic) & 0.000000 & & \\
\hline
\end{tabular}

\subsection{Identification and Estimation}

Based on the ACF and PACF correlation chart for the log (arr) series in Figure 5, possible ARMA models are identified based on the lags that exceed the confidence band for autocorrelation and partial correlation. Thus, it is found that the possible models are $\mathrm{AR}(1) \mathrm{MA}(1)$ and $\mathrm{AR}(1) \mathrm{MA}(2)$, according to Figure 5.
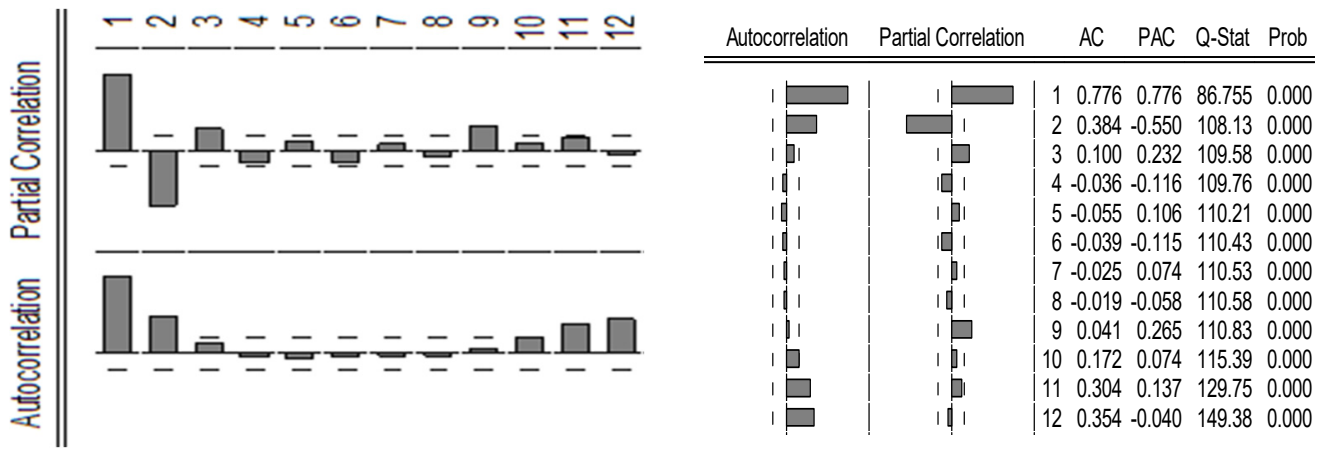

Figure 5. Correlogram for $\log$ (arr) series.

The lags exceeding the confidence band for autocorrelation are 1 and 2, and for partial correlation, the lags exceeding the confidence band are 1 and 2 . Thus, the possible values for $\mathrm{p}$ for $\mathrm{AR}$ are 1 or 2; those for $\mathrm{q}$ corresponding to MA are 1 and 2 . Therefore, the possible models are AR(1)MA(1) and AR(1)MA(2). We tested the two possible ARMA models, namely:

- $\quad$ Model A: AR(1)MA(1) in Table 4;

- $\quad$ Model B: AR(1)MA(2) in Table 5. 
Table 4. AR(1)MA(1) Model A.

\begin{tabular}{ccccc}
\hline Variable & Coefficient & Std. Error & t-Statistic & Prob. \\
\hline C & 13.43362 & 0.155971 & 86.12880 & 0.0000 \\
AR(1) & 0.607583 & 0.039802 & 15.26505 & 0.0000 \\
MA(1) & 0.822821 & 0.053136 & 15.48528 & 0.0000 \\
SIGMASQ & 0.080048 & 0.004732 & 16.91652 & 0.0000 \\
\hline R-squared & 0.765493 & Mean dependent var & 13.44107 \\
Adjusted R-squared & 0.760357 & S.D. dependent var & 0.586329 \\
S.E. of regression & 0.287027 & Akaike information criterion & 0.386513 \\
Sum squared resid & 11.28670 & Schwarz criterion & 0.470166 \\
Log likelihood & -23.24919 & Hannan-Quinn criterion & 0.420507 \\
F-statistic & 149.0678 & Durbin-Watson stat & 1.864215 \\
Prob(F-statistic) & 0.000000 & & \\
Inverted AR Roots & \multicolumn{2}{c}{0.61} & & \\
Inverted MA Roots & \multicolumn{2}{c}{. } & \\
\hline
\end{tabular}

Table 5. AR(1)MA(2) Model B.

\begin{tabular}{ccccc}
\hline Variable & Coefficient & Std. Error & t-Statistic & Prob. \\
\hline C & 13.40056 & 0.207699 & 64.51900 & 0.0000 \\
AR(1) & 0.960986 & 0.035982 & 26.70753 & 0.0000 \\
MA(2) & -0.761904 & 0.096825 & -7.868843 & 0.0000 \\
SIGMASQ & 0.112022 & 0.005369 & 20.86579 & 0.0000 \\
\hline R-squared & 0.671820 & Mean dependent var & 13.44107 \\
Adjusted R-squared & 0.664633 & S.D. dependent var & 0.586329 \\
S.E. of regression & 0.339548 & Akaike information criterion & 0.718858 \\
Sum squared resid & 15.79512 & Schwarz criterion & 0.802510 \\
Log likelihood & -46.67946 & Hannan-Quinn criterion & 0.752851 \\
F-statistic & 93.48447 & Durbin-Watson stat & 0.986999 \\
Prob (F-statistic) & 0.000000 & & \\
Inverted AR Roots & \multicolumn{3}{c}{-0.87} \\
Inverted MA Roots & 0.96 & \multicolumn{2}{c}{}
\end{tabular}

The best model must be stationary and parsimonious that fits the data well. Model selection criteria are: Sigma SQ, AIC (Akaike information criterion); SBIC (Schwarz Bayesian information criterion); HQIC (Hannan-Quinn information criterion); and Durbin-Watson (DW) statistics which are centralized in Table 6, and according to which the best model is Model A, i.e., AR(1)MA(1).

Table 6. Model comparison-choosing the best ARMA model.

\begin{tabular}{cccc}
\hline Criteria & $\begin{array}{c}\text { Model A } \\
\text { ARMA (1,1) }\end{array}$ & $\begin{array}{c}\text { Model B } \\
\text { ARMA (1,2) }\end{array}$ & Best Model \\
\hline C, AR and MA & $2 / 2$ & $3 / 3$ & Model A and Model B \\
Sigma SQ & 0.08 & 0.11 & Model A (smaller is better) \\
Log likelihood & -23.24 & -46.67 & Model A (Bigger is better) \\
AIC & 0.38 & 0.71 & Model A (smaller is better) \\
SBIC & 0.47 & 0.80 & Model A (smaller is better) \\
HQIC & 0.42 & 0.75 & Model A (smaller is better) \\
DW & 1.86 & 0.98 & Model A (closer to 2 is better) \\
\hline Best Model & \multicolumn{3}{c}{ Model A } \\
\hline
\end{tabular}

Note: author's own calculation.

Table 6 indicates best model: Sigma SQ, AIC: Akaike information criterion; SBIC: Schwarz Bayesian Information Criterion, HQIC: Hannan-Quinn information criterion and DW Durbin-Watson statistic. 


\subsection{Diagnosis and Forecasting}

In order to determine whether the forecast can be made using the potential candidate model, Model A-AR(1)MA(1), we needed to test whether it meets the conditions to be considered a stable univariate process:

- We need to check if Residuals of the potential model can be considered White Noise, so applied the Ljung-Box Q statistic. We start from:

Hypothesis H0. Residuals are White Noise.

By applying Ljung-Box Q statistic for the potential model AR(1)MA(1), it is observed that the $p$ Value associated with the $\mathrm{Q}$ statistic $>0.05$; thus, we cannot reject the null hypothesis, i.e., residuals are White Noise (Table 7).

Table 7. Q-statistic probabilities adjusted for 2 ARMA terms.

\begin{tabular}{|c|c|c|c|c|c|c|c|c|}
\hline \multicolumn{2}{|c|}{ Autocorrelation } & \multicolumn{2}{|c|}{ Partial Correlation } & & \multirow{2}{*}{$\begin{array}{c}\text { AC } \\
0.060\end{array}$} & \multirow{2}{*}{$\begin{array}{c}\text { PAC } \\
0.060\end{array}$} & \multirow{2}{*}{$\frac{\text { Q-Stat }}{0.5236}$} & \multirow[t]{2}{*}{ Prob } \\
\hline .1. & I & .1. & I & 1 & & & & \\
\hline .1 & I & .1. & I & 2 & 0.021 & 0.018 & 0.5900 & \\
\hline$* 1$. & । & $* 1$. & I & 3 & -0.135 & -0.138 & 3.2684 & 0.071 \\
\hline$* 1$. & । & $* 1$. & I & 4 & -0.131 & -0.117 & 5.7781 & 0.056 \\
\hline .1. & I & .1 & I & 5 & 0.014 & 0.035 & 5.8068 & 0.121 \\
\hline .1 & i & $* 1$. & I & 6 & -0.051 & -0.068 & 6.2024 & 0.185 \\
\hline .1 & I & .1 & I & 7 & 0.069 & 0.042 & 6.9105 & 0.227 \\
\hline$* 1$. & । & $* 1$. & । & 8 & -0.078 & -0.093 & 7.8357 & 0.250 \\
\hline$* 1$. & I & $* 1$. & I & 9 & -0.103 & -0.112 & 9.4502 & 0.222 \\
\hline $.1^{*}$ & I & $.1^{*}$ & 1 & 10 & 0.091 & 0.113 & 10.722 & 0.218 \\
\hline .1 & I & .1 & I & 11 & 0.041 & 0.030 & 10.979 & 0.277 \\
\hline $.1^{* *}$ & I & $.1^{* *}$ & I & 12 & 0.309 & 0.264 & 25.925 & 0.004 \\
\hline
\end{tabular}

- $\quad$ Check if the estimated ARMA process is (covariance) stationary: AR roots should lie inside the unit circle;

- Check if the estimated ARMA process is invertible: all MA roots should lie inside the unit circle.

If the conditions are satisfied, we can forecast with this potential model AR(1)MA(1), but if the conditions are not satisfied, we need to repeat the selection and estimation method, according to Table 8 and Figure 6.

Table 8. AR/MA Roots.

\begin{tabular}{|c|c|c|c|}
\hline AR $\operatorname{Root}(s)$ & Modulus & Cycle & Observation \\
\hline 0.607583 & 0.607583 & & $\begin{array}{l}\text { No root lies outside the unit circle. } \\
\text { ARMA model is stationary. }\end{array}$ \\
\hline MA Root(s) & Modulus & Cycle & \\
\hline-0.822821 & 0.822821 & & $\begin{array}{l}\text { No root lies outside the unit circle. } \\
\text { ARMA model is invertible. }\end{array}$ \\
\hline
\end{tabular}

Thus, AR roots should lie inside the unit circle, and we can say the estimated ARMA process is (covariance) stationary, and although all MA roots should lie inside the unit circle, the estimated ARMA process is invertible.

Thus, if the conditions are satisfied, we can forecast with the model AR(1)MA(1). It can be seen from Figure 7 that the tested model AR(1)MA(1) approximates the past evolution very well, and that the residuals exceed the confidence interval only during the pandemic and post-pandemic periods, in 2020 and 2021, respectively. 


\section{Log(arr): Inverse Roots of AR/MA Polynomial(s)}

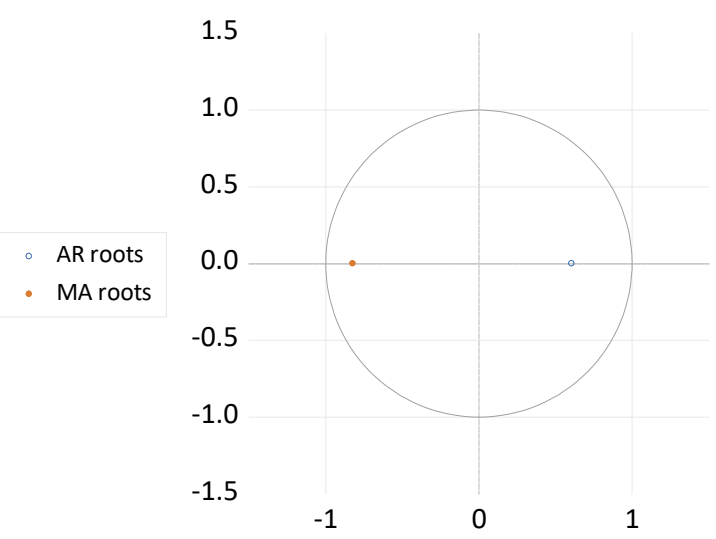

Figure 6. AR/MA roots.

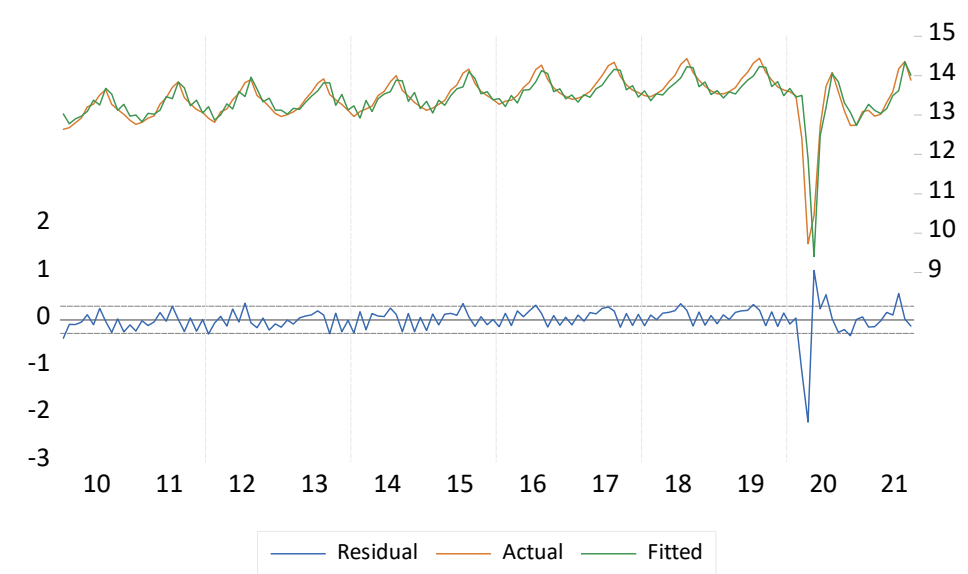

Figure 7. Residual, actual and fitted values.

Forecast for the AR(1)MA(1) model can be seen in Figure 8 .


b) Evolution for Log(arr) by Season
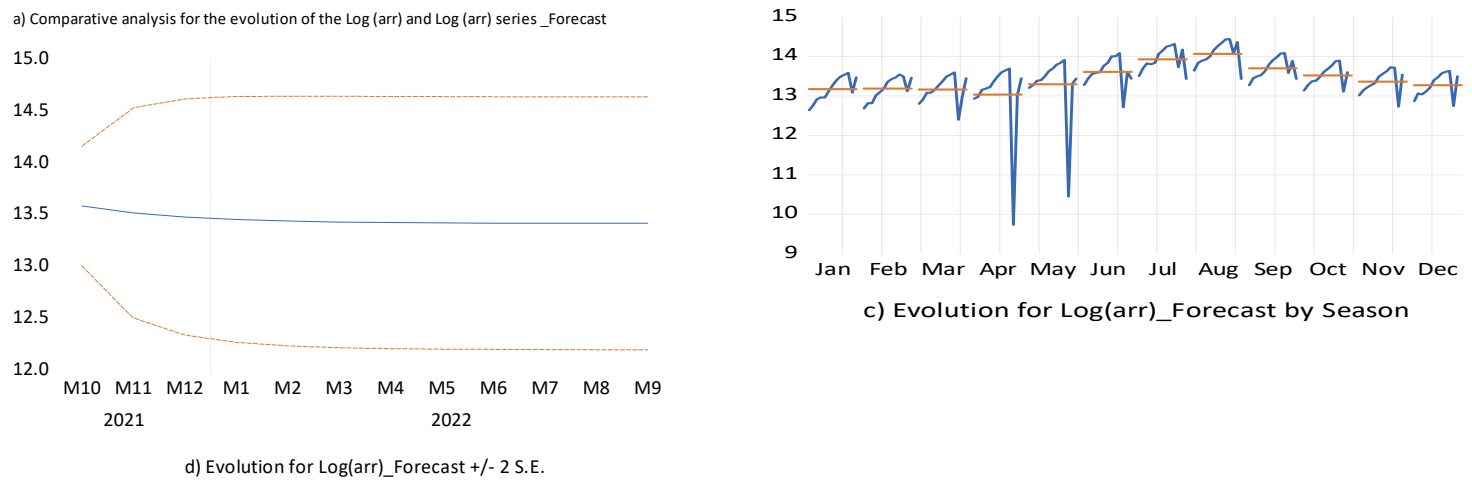

c) Evolution for Log(arr)_Forecast by Season

Figure 8. Forecast for AR(1)MA(1). 
Based on the analyses in Figure 8 and Table 9, it can be seen that the chosen model of type $\operatorname{AR}(1) \mathrm{MA}(1)$, on the basis of which the forecast for arrivals in Romania is made, perfectly approximates the previous evolution of arrivals.

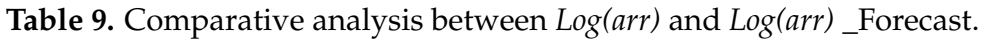

\begin{tabular}{|c|c|c|c|c|c|c|c|c|c|c|c|c|c|}
\hline & M1 & M2 & M3 & M4 & M5 & M6 & M7 & M8 & M9 & M10 & M11 & M12 & Year \\
\hline Year & & & \multicolumn{10}{|c|}{2010} & 2010 \\
\hline $\log (a r r)$ & 12.6 & 12.7 & 12.8 & 12.9 & 13.2 & 13.3 & 13.5 & 13.6 & 13.3 & 13.1 & 13.0 & 12.9 & 13.1 \\
\hline Log(arr)_Forecast & 12.6 & 12.7 & 12.8 & 12.9 & 13.2 & 13.3 & 13.5 & 13.6 & 13.3 & 13.1 & 13.0 & 12.9 & 13.1 \\
\hline Year & & & \multicolumn{10}{|c|}{2011} & 2011 \\
\hline $\log (a r r)$ & 12.8 & 12.8 & 12.9 & 13.0 & 13.3 & 13.4 & 13.7 & 13.8 & 13.4 & 13.3 & 13.1 & 13.1 & 13.2 \\
\hline Log(arr)_Forecast & 12.8 & 12.8 & 12.9 & 13.0 & 13.3 & 13.4 & 13.7 & 13.8 & 13.4 & 13.3 & 13.1 & 13.1 & 13.2 \\
\hline Year & & & \multicolumn{10}{|c|}{2012} & 2012 \\
\hline $\log (a r r)$ & 12.9 & 12.8 & 13.1 & 13.2 & 13.4 & 13.6 & 13.8 & 13.9 & 13.5 & 13.4 & 13.2 & 13.0 & 13.3 \\
\hline Log(arr)_Forecast & 12.9 & 12.8 & 13.1 & 13.2 & 13.4 & 13.6 & 13.8 & 13.9 & 13.5 & 13.4 & 13.2 & 13.0 & 13.3 \\
\hline Year & & & \multicolumn{10}{|c|}{2013} & 2013 \\
\hline $\log (a r r)$ & 13.0 & 13.0 & 13.1 & 13.2 & 13.4 & 13.6 & 13.8 & 13.9 & 13.5 & 13.4 & 13.3 & 13.1 & 13.4 \\
\hline Log(arr)_Forecast & 13.0 & 13.0 & 13.1 & 13.2 & 13.4 & 13.6 & 13.8 & 13.9 & 13.5 & 13.4 & 13.3 & 13.1 & 13.4 \\
\hline Year & & & \multicolumn{10}{|c|}{2014} & 2014 \\
\hline $\log (a r r)$ & 13.0 & 13.1 & 13.2 & 13.2 & 13.5 & 13.6 & 13.8 & 14.0 & 13.6 & 13.5 & 13.3 & 13.2 & 13.4 \\
\hline Log(arr)_Forecast & 13.0 & 13.1 & 13.2 & 13.2 & 13.5 & 13.6 & 13.8 & 14.0 & 13.6 & 13.5 & 13.3 & 13.2 & 13.4 \\
\hline Year & & & \multicolumn{10}{|c|}{2015} & 2015 \\
\hline $\log (\operatorname{arr})$ & 13.1 & 13.2 & 13.3 & 13.4 & 13.6 & 13.8 & 14.1 & 14.2 & 13.8 & 13.6 & 13.5 & 13.4 & 13.6 \\
\hline Log(arr)_Forecast & 13.1 & 13.2 & 13.3 & 13.4 & 13.6 & 13.8 & 14.1 & 14.2 & 13.8 & 13.6 & 13.5 & 13.4 & 13.6 \\
\hline Year & & & \multicolumn{10}{|c|}{2016} & 2016 \\
\hline $\log (a r r)$ & 13.3 & 13.4 & 13.4 & 13.5 & 13.7 & 13.8 & 14.2 & 14.3 & 13.9 & 13.7 & 13.6 & 13.5 & 13.7 \\
\hline Log(arr)_Forecast & 13.3 & 13.4 & 13.4 & 13.5 & 13.7 & 13.8 & 14.2 & 14.3 & 13.9 & 13.7 & 13.6 & 13.5 & 13.7 \\
\hline Year & & & \multicolumn{10}{|c|}{2017} & 2017 \\
\hline $\log (\operatorname{arr})$ & 13.4 & 13.4 & 13.5 & 13.6 & 13.8 & 14.0 & 14.3 & 14.3 & 14.0 & 13.8 & 13.6 & 13.6 & 13.8 \\
\hline Log(arr)_Forecast & 13.4 & 13.4 & 13.5 & 13.6 & 13.8 & 14.0 & 14.3 & 14.3 & 14.0 & 13.8 & 13.6 & 13.6 & 13.8 \\
\hline Year & & & \multicolumn{10}{|c|}{2018} & 2018 \\
\hline $\log (a r r)$ & 13.5 & 13.5 & 13.5 & 13.6 & 13.8 & 14.0 & 14.3 & 14.4 & 14.1 & 13.9 & 13.7 & 13.6 & 13.8 \\
\hline Log(arr)_Forecast & 13.5 & 13.5 & 13.5 & 13.6 & 13.8 & 14.0 & 14.3 & 14.4 & 14.1 & 13.9 & 13.7 & 13.6 & 13.8 \\
\hline Year & & & \multicolumn{10}{|c|}{2019} & 2019 \\
\hline $\log (a r r)$ & 13.5 & 13.5 & 13.6 & 13.7 & 13.9 & 14.1 & 14.3 & 14.4 & 14.1 & 13.9 & 13.7 & 13.6 & 13.9 \\
\hline Log(arr)_Forecast & 13.5 & 13.5 & 13.6 & 13.7 & 13.9 & 14.1 & 14.3 & 14.4 & 14.1 & 13.9 & 13.7 & 13.6 & 13.9 \\
\hline Year & & & \multicolumn{10}{|c|}{2020} & 2020 \\
\hline $\log (a r r)$ & 13.6 & 13.5 & 12.4 & 9.7 & 10.5 & 12.7 & 13.7 & 14.1 & 13.6 & 13.1 & 12.7 & 12.7 & 12.7 \\
\hline Log(arr)_Forecast & 13.6 & 13.5 & 12.4 & 9.7 & 10.5 & 12.7 & 13.7 & 14.1 & 13.6 & 13.1 & 12.7 & 12.7 & 12.7 \\
\hline Year & & & \multicolumn{10}{|c|}{2021} & 2021 \\
\hline $\log (a r r)$ & 13.1 & 13.1 & 13.0 & 13.0 & 13.3 & 13.6 & 14.2 & 14.4 & 13.9 & - & - & - & 13.5 \\
\hline Log(arr)_Forecast & 13.1 & 13.1 & 13.0 & 13.0 & 13.3 & 13.6 & 14.2 & 14.4 & 13.9 & 13.6 & 13.5 & 13.5 & 13.5 \\
\hline Year & & & \multicolumn{10}{|c|}{2022} & 2022 \\
\hline $\log (a r r)$ & - & - & - & - & - & - & - & - & - & - & - & - & - \\
\hline Log(arr)_Forecast & 13.5 & 13.5 & 13.4 & 13.4 & 13.4 & 13.4 & 13.4 & 13.4 & 13.4 & - & - & - & 13.4 \\
\hline
\end{tabular}

This chosen model offers us the possibility to estimate the values of the flow of tourists from Romania, which is of great practical importance for the decision-making bodies in the field of tourism which can thus adapt their policies and strategies in the field of tourism according to these forecasted values to mitigate the negative effects of the current pandemic and uncertainty on Romanian tourism.

The existence of a model that predicts how tourist activity will evolve is very useful for adapting tourism policies according to the expected results that can be estimated for the next period. 
Additionally, depending on the estimated values for the flow of tourists, it is possible to estimate the necessary personnel in the field and the correlation of the policies for establishing the quotas of migrants that can be employed in the tourism field, considering the fact that Romania is facing a personnel crisis in the field of tourist services.

\section{Discussion}

We have applied the ARMA method starting from the fact that the analyzed activity has a seasonal component, and the analyzed series regarding the tourist arrivals was not stationary.

Based on the studies performed, we found that the tourism phenomenon in Romania can be predicted using an AR(1)MA(1) model that accurately describes the previous evolution of the series of arrivals. The only deviations from the residuals for the forecast model from the confidence interval occurred during the pandemic, because due to the lockdowns, the tourism sector was particularly affected.

If we used only the computerized analysis of the tourism phenomenon in Romania with the help of EViews, it established that the best forecast model for the arr series is also AR(1)MA(1) (Table 10).

Table 10. Automatic ARIMA forecasting.

\begin{tabular}{|c|c|c|c|c|}
\hline \multicolumn{5}{|c|}{ Selected Dependent Variable: LOG(ARRIVALS) } \\
\hline \multirow{4}{*}{\multicolumn{5}{|c|}{$\begin{array}{l}\text { Number of estimated ARMA models: } 1521 \\
\text { Number of non-converged estimations: } 4 \\
\text { Selected ARMA model: }(1,1)(1,1) \\
\text { AIC value: } 0.217870160741\end{array}$}} \\
\hline & & & & \\
\hline & & & & \\
\hline & & & & \\
\hline Variable & Coefficient & Std. Error & t-Statistic & Prob. \\
\hline C & 13.40016 & 0.345544 & 38.77988 & 0.0000 \\
\hline $\operatorname{AR}(1)$ & 0.602030 & 0.048188 & 12.49348 & 0.0000 \\
\hline $\operatorname{SAR}(12)$ & 0.951003 & 0.087732 & 10.83989 & 0.0000 \\
\hline $\mathrm{MA}(1)$ & 0.821729 & 0.077311 & 10.62886 & 0.0000 \\
\hline $\operatorname{SMA}(12)$ & -0.780987 & 0.164679 & -4.742496 & 0.0000 \\
\hline SIGMASQ & 0.062633 & 0.003186 & 19.66038 & 0.0000 \\
\hline R-squared & 0.816511 & \multicolumn{2}{|c|}{ Mean dependent var } & 13.44107 \\
\hline Adjusted R-squared & 0.809715 & \multicolumn{2}{|c|}{ S.D. dependent var } & 0.586329 \\
\hline S.E. of regression & 0.255766 & \multicolumn{2}{|c|}{ Akaike information criterion } & 0.217870 \\
\hline Sum squared residual & 8.831210 & \multicolumn{2}{|c|}{ Schwarz criterion } & 0.343349 \\
\hline Log likelihood & -9.359846 & \multicolumn{2}{|c|}{ Hannan-Quinn criterion } & 0.268861 \\
\hline F-statistic & 120.1478 & \multicolumn{2}{|c|}{ Durbin-Watson stat } & 1.876450 \\
\hline Prob(F-statistic) & 0.000000 & & & \\
\hline \multirow[t]{4}{*}{ Inverted AR Roots } & 1.00 & $0.86-0.50 \mathrm{i}$ & $0.86+0.50 \mathrm{i}$ & 0.60 \\
\hline & $0.50-0.86 \mathrm{i}$ & $0.50+0.86 \mathrm{i}$ & $0.00-1.00 \mathrm{i}$ & $-0.00+1.00 \mathrm{i}$ \\
\hline & $-0.50+0.86 \mathrm{i}$ & $-0.50-0.86 \mathrm{i}$ & $-0.86+0.50 \mathrm{i}$ & $-0.86-0.50 \mathrm{i}$ \\
\hline & \multicolumn{3}{|c|}{-1.00} & \\
\hline \multirow[t]{3}{*}{ Inverted MA Roots } & 0.98 & $0.85+0.49 \mathrm{i}$ & $0.85-0.49 \mathrm{i}$ & $0.49-0.85 i$ \\
\hline & $0.49+0.85 \mathrm{i}$ & $0.00+0.98 \mathrm{i}$ & $-0.00-0.98 \mathrm{i}$ & $-0.49-0.85 \mathrm{i}$ \\
\hline & $-0.49+0.85 \mathrm{i}$ & -0.82 & $-0.85-0.49 \mathrm{i}$ & $-0.85+0.49 \mathrm{i}$ \\
\hline
\end{tabular}

The criteria on the basis of which the forecast model is chosen by EViews software are given in Table 11 and Figure 9.

Starting from what is known as ARMA analysis, which is more an art than a science, because there is no perfect model or true model, we chose that model with which the forecast will be made only if the specialist considers that it meets the absolutely necessary requirements. Therefore, the automatic application of the methods offered by machine learning must be completed with an analysis assisted by a researcher who may or may not confirm the chosen model automatically. 
Table 11. Choosing the best ARMA model using EViews.

\begin{tabular}{ccccc}
\hline Model & LogL & AIC * & BIC & HQ \\
\hline$(1,1)(1,1)$ & -9.359846 & 0.217870 & 0.343349 & 0.268861 \\
$(2,1)(1,1)$ & -8.532700 & 0.220322 & 0.366714 & 0.279811 \\
$(1,2)(1,1)$ & -8.568524 & 0.220830 & 0.367222 & 0.280319 \\
$(1,1)(2,0)$ & -10.135520 & 0.228873 & 0.354352 & 0.279863 \\
$(1,1)(2,1)$ & -9.237388 & 0.230318 & 0.376710 & 0.289806 \\
$(1,1)(1,2)$ & -9.271864 & 0.230807 & 0.377199 & 0.290295 \\
$(0,3)(1,1)$ & -9.304888 & 0.231275 & 0.377667 & 0.290764 \\
$(2,1)(2,0)$ & -9.380115 & 0.232342 & 0.378734 & 0.291831 \\
$(1,2)(2,0)$ & -9.452434 & 0.233368 & 0.379760 & 0.292857 \\
$(2,1)(2,1)$ & -8.482311 & 0.233792 & 0.401097 & 0.301779 \\
$(1,3)(1,1)$ & -8.483892 & 0.233814 & 0.401120 & 0.301801 \\
$(2,1)(1,2)$ & -8.497281 & 0.234004 & 0.401310 & 0.301991 \\
$(1,2)(2,1)$ & -8.514241 & 0.234245 & 0.401550 & 0.302232 \\
\hline
\end{tabular}

Akaike Information Criteria (top 20 models)

0.245

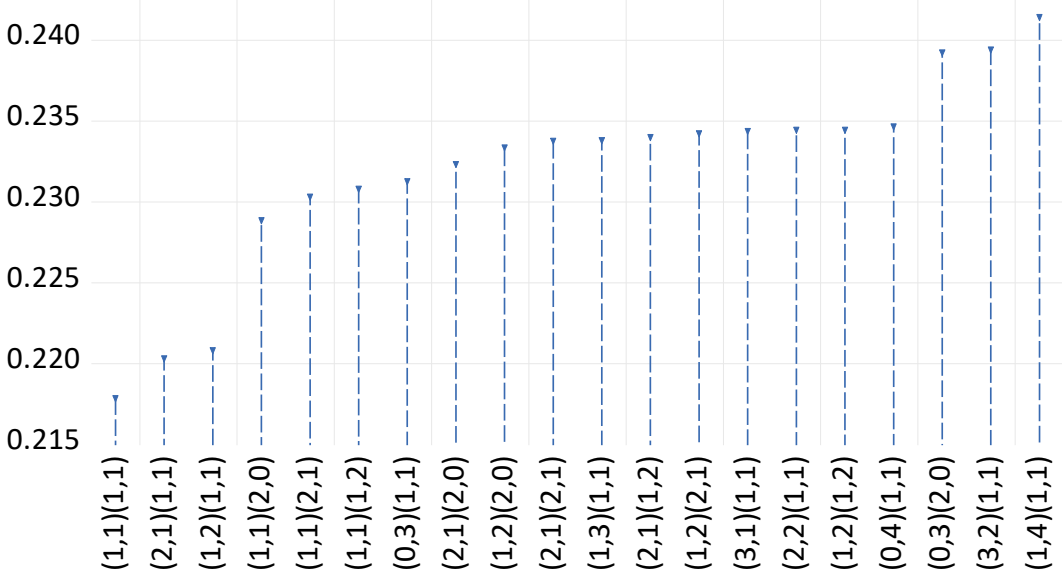

Figure 9. Choosing the best ARMA model according to the AIC criterion using EViews.

In this paper, we have studied two ARMA-type models econometrically starting from the idea that the tourist activity is a seasonal and non-stationary one. Thus, through the comparative analysis of the models $\mathrm{AR}(1) \mathrm{MA}(1)$ and $\mathrm{AR}(1) \mathrm{MA}(2)$ we demonstrated that for the tourist flow in Romania can be forecast with the help of the model AR(1)MA(1), as we have searched a stationary and parsimonious model that fits the data well. Model selection criteria were: significance of the ARMA components, compare Akaike, Schwartz and Hannan-Quinn, and Durbin-Watson statistic. We found that the tourism phenomenon in Romania can be predicted using an $\mathrm{AR}(1) \mathrm{MA}(1)$-type model that meets the requirements for a stable univariate process and that it accurately describes the previous evolution of the series of arrivals. The only deviations from the residuals for the forecast model away from the confidence interval occurred during the pandemic, because due to the lockdowns, the tourism sector was particularly affected. We can say that for a short and medium time, the forecast with such a model is almost identical to reality.

In our study, the model automatically chosen by the software is the same as the one we found by reviewing the entire econometric methodology; therefore, the model with which we made the forecast for the tourist flow in Romania was the AR model (1) MA(1).

This paper is subject to study limitations, but may also suggest additional lines of research. This approach to tourism demand forecasting may continue in the future with interest for researchers by expanding the geographical area or pursuing tourism activity following this study, or may serve as a starting point for further research. 
The tourism phenomenon is a very important field for Romania, and the effects generated by the COVID-19 pandemic on it are both social and economic, which is why a series of coherent measures are needed to resume and boost domestic tourism, as well as external tourism.

\section{Conclusions}

Tourism has been one of the sectors most affected globally due to the restrictions imposed during the COVID-19 pandemic, but also the reluctance of consumers to travel. Romania is no exception. Many holidays have been canceled during lockdowns and travel budgets have been tightened. As governments work to limit the spread of new, increasingly contagious strains of COVID-19, the tourism industry is hoping for an economic recovery. However, "green certificates" are not enough to relaunch tourism, which is only expected to return to pre-pandemic values in 2024.

The particularities of tourist services determine the fact there are many factors which influence the tourist demand, so that the prediction of the tourist demand becomes more complex and uncertain.

Knowing that the tourism system is affected, and it must respond to a growing number of global challenges, including the continuing uncertainty surrounding the health crisis and other challenges related to the market preferences of major tourism flows in emerging economies, new realities of mobility related to travel restrictions, the need for forecasting is necessary. In the hospitality industry, the idea that planning and forecasting activities are exclusively a function of management has been rejected. This appears at all levels, from the government downwards. Workers must consider the elements of the forecast so that the activity can be carried out successfully, but also the knowledge of how to predict market trends in order to be prepared for customer requests. During the COVID-19 pandemic, the global tourism industry suffered considerably, and many countries are trying to make forecasts and plans in order to recover tourism.

Tourism demand forecasting is a relevant and stimulating topic for various actors involved in the tourism sector, such as practitioners and policy makers. Access to good forecasts would help these agents anticipate future tourism demand and adapt their supply capacity conveniently, as well as optimize their human resources. Resources related to tourism could be allocated more efficiently, and the sector could produce more profit. For this reason, it is crucial for researchers and operational managers to choose a forecasting method that provides good predictive accuracy.

This study is apt because it addresses the severely affected tourist activity in a pandemic context, and it has both a theoretical applicability, by determining a model with which to predict the flow of tourists from Romania; and practically, it can estimate the values of tourist arrivals and enables the decision-making bodies in the field to take the necessary measures to mitigate the negative effects of the pandemic on this sector of the Romanian economy. For tourism decision makers, knowing a forecast of the trend for the flow of tourist arrivals in the short and medium term is useful for adopting strategies to support this field in the post-pandemic period. Additionally, the possibility to forecast the flow of tourist arrivals is useful for anticipating the necessary workforce in the field of tourist services.

The pandemic was a real shock for the Romanian tourism industry; therefore, we intend to study future if the reduction in the number of tourist arrivals was only temporary, being the manifestation of the shock, or whether the downward trend will continue in the future. We also intend to study in our future research on tourism activity whether the chosen model of type AR(1)MA(1) is suitable for other datasets, such as domestic or international arrivals.

Author Contributions: All authors have an equal contribution to the publication. All authors have read and agreed to the published version of the manuscript. 
Funding: This work was supported by the Danubius University of Galati, Romania and is part of the research of Research Center on Socio-Economic Dynamics in Sustainable Development (DISEDD) Research Lab.

\section{Institutional Review Board Statement: Not applicable.}

Informed Consent Statement: Informed consent was obtained from all subjects involved in the study.

Data Availability Statement: Data supporting reported results can be found at the authors of the study.

Conflicts of Interest: The authors declare no conflict of interest.

\section{References}

1. World Travel \& Tourism Council. Economic Impact 2021; World Travel \& Tourism Council: London, UK, 2021.

2. UNWTO World Tourism Barometer and Statistical Annex, January 2020. UNWTO World Tour. Barom. (Engl. Version) 2020, 18, 1-48. [CrossRef]

3. Ghaderi, Z.; Mat Som, A.P.; Wang, J. Organizational learning in tourism crisis management: An experience from Malaysia. J. Travel Tour. Mark. 2014, 31, 627-648. [CrossRef]

4. Kenny, J.; Dutt, C.S. The long-term impacts of hotel's strategic responses to COVID-19: The case of Dubai. Tour. Hosp. Res. 2021, 22, 71-85. [CrossRef]

5. Rindrasih, E.; Witte, P.A.; Spit, T.J.M.; Zoomers, E.B. Tourism and disasters: Impact of disaster events on tourism development in Indonesia 1998-2016 and structural approach policy responses. J. Serv. Sci. Manag. 2019, 12, 93-115. [CrossRef]

6. Sigala, M. Tourism and COVID-19: Impacts and implications for advancing and resetting industry and research. J. Bus. Res. 2020, 117, 312-321. [CrossRef]

7. Zhang, H.; Zhuang, M.; Cao, Y.; Pan, J.; Zhang, X.; Zhang, J.; Zhang, H. Social Distancing in Tourism Destination Management during the COVID-19 Pandemic in China: A Moderated Mediation Model. Int. J. Environ. Res. Public Health 2021, $18,11223$. [CrossRef]

8. Sharma, G.D.; Thomas, A.; Paul, J. Reviving tourism industry post-COVID-19: A resilience-based framework. Tour Manag. Perspect. 2021, 37, 100786. [CrossRef]

9. Arbulú, I.; Razumova, M.; Rey-Maquieira, J.; Sastre, F. Measuring risks and vulnerability of tourism to the COVID-19 crisis in the context of extreme uncertainty: The case of the Balearic Islands. Tour. Manag. Perspect. 2021, 39, 100857. [CrossRef]

10. Fodness, D. Measuring tourist motivation. Ann. Tour. Res. 1994, 21, 555-581. [CrossRef]

11. Mahika, E.-C. Current trends in tourist motivation. Cactus Tour. J. 2011, 2, 15-24.

12. Carvache-Franco, M.; Carvache-Franco, W.; Víquez-Paniagua, A.G.; Carvache-Franco, O.; Pérez-Orozco, A. The Role of Motivations in the Segmentation of Ecotourism Destinations: A Study from Costa Rica. Sustainability 2021, 13, 9818. [CrossRef]

13. Radulescu, C.V.; Ladaru, G.-R.; Burlacu, S.; Constantin, F.; Ioanăs, C.; Petre, I.L. Impact of the COVID-19 Pandemic on the Romanian Labor Market. Sustainability 2021, 13, 271. [CrossRef]

14. Abbas, J.; Mubeen, R.; Terhemba Iorember, P.T.; Raza, S.; Mamirkulova, G. Exploring the impact of COVID-19 on tourism: Transformational potential and implications for a sustainable recovery of the travel and leisure industry. Curr. Res. Behav. Sci. 2021, 2, 100033. [CrossRef]

15. UNWTO. Impact Assessment of the Covid-19 Outbreak on International Tourism. 2020. Available online: https://Www.Unwto. Org/Impact-Assessment-of-the-Covid-19-Outbreak-on-International-Tourism (accessed on 15 November 2021).

16. Jamal, T.; Budke, C. Tourism in a world with pandemics: Local-global responsibility and action. J. Tour. Futures. 2020, 6, 181-188. [CrossRef]

17. Chang, C.L.; McAleer, M.; Ramos, V. A charter for sustainable tourism after COVID-19. Sustainability 2020, 12, 3671. [CrossRef]

18. Cheer, J.M. Human Flourishing, Tourism Transformation and COVID-19: A Conceptual Touchstone. Tour. Geogr. 2020, 22, 514-524. [CrossRef]

19. Barcaccia, G.; D'Agostino, V.; Zotti, A.; Cozzi, B. Impact of the SARS-CoV-2 on the Italian Agri-Food Sector: An Analysis of the Quarter of Pandemic Lockdown and Clues for a Socio-Economic and Territorial Restart. Sustainability 2020, 12, 5651. [CrossRef]

20. Hao, F.; Xiao, Q.; Chon, K. COVID-19 and China's Hotel Industry: Impacts, a Disaster Management Framework, and PostPandemic Agenda. Int. J. Hosp. Manag. 2020, 90, 102636. [CrossRef]

21. Coluccia, B.; Agnusdei, G.P.; Miglietta, P.P.; De Leo, F. Effects of COVID-19 on the Italian agri-food supply and value chains. Food Control 2021, 123, 107839. [CrossRef]

22. Kaushal, V.; Srivastava, S. Hospitality and tourism industry amid COVID-19 pandemic: Perspectives on challenges and learnings from India. Int. J. Hosp. Manag. 2021, 92, 102707. [CrossRef]

23. Alonso, A.D.; Kok, S.K.; Bressan, A.; O'Shea, M.; Sakellarios, N.; Koresis, A. COVID-19, aftermath, impacts, and hospitality firms: An international perspective. Int. J. Hosp. Manag. 2020, 91, 102654. [CrossRef] [PubMed]

24. Divya, A. Hospitality Sector Gears up for a New Post-Lockdown Normal. 2020. Available online: https://indianexpress.com/ article/business/hospitality-sector-gears-up-for-a-new-post-lockdown-normal-6482394/ (accessed on 1 December 2021). 
25. Rodríguez-Antón, J.M.; Alonso-Almeida, M.d.M. COVID-19 Impacts and Recovery Strategies: The Case of the Hospitality Industry in Spain. Sustainability 2020, 12, 8599. [CrossRef]

26. Chang, C.L.; McAleer, M.; Ramos, V. The future of tourism in the COVID-19 Era. Adv. Decis. Sci. 2020, 24, 218-230.

27. Badulescu, A.; Badulescu, D.; Simut, R.; Dzitac, S. Tourism-Economic growth nexus. The case of Romania. Technol. Econ. Dev. Econ. 2020, 26, 867-884. [CrossRef]

28. Álvarez-Díaz, M.; González-Gómez, M.; Otero-Giráldez, M.S. Forecasting International Tourism Demand Using a Non-Linear Autoregressive Neural Network and Genetic Programming. Forecasting 2019, 1, 90-106. [CrossRef]

29. Jun, W.; Yuyan, L.; Lingyu, T.; Peng, G. Modeling a combined forecast algorithm based on sequence patterns and near characteristics: An application for tourism demand forecasting. Chaos Solitons Fractals 2018, 108, 136-147. [CrossRef]

30. Witt, S.F.; Witt, C.A. Modeling and Forecasting Demand in Tourism; Academic Press: London, UK, $1992 ;$ p. 199.

31. Tukamushaba, E.K.; Shanshan Lin, V.S.; Bwire, T. Modeling and Forecasting Inbound Tourism Demand for Long-Haul Markets of Beijing. J. China Tour. Res. 2013, 9, 489-506. [CrossRef]

32. Saayman, A.; Botha, I. Non-linear models for tourism demand forecasting. Tour. Econ. 2017, 23, 594-613. [CrossRef]

33. Di Crosta, A.; Ceccato, I.; Marchetti, D.; La Malva, P.; Maiella, R.; Cannito, L.; Cipi, M.; Mammarella, N.; Palumbo, R.; Verrocchio, M.C.; et al. Psychological factors and consumer behavior during the COVID-19 pandemic. PLoS ONE 2021, 16, e0256095. [CrossRef]

34. Sharma, P.; Leung, T.Y.; Kingshott, R.P.J.; Davcik, N.S.; Cardinali, S. Managing uncertainty during a global pandemic: An international business perspective. J. Bus. Res. 2020, 116, 188-192. [CrossRef]

35. Chen, J.L.; Li, G.; Wu, D.C.; Shen, S. Forecasting Seasonal Tourism Demand Using a Multiseries Structural Time Series Method. J. Travel Res. 2019, 58, 92-103. [CrossRef]

36. Makridakis, S.; Hogarth, R.M.; Gaba, A. Forecasting and uncertainty in the economic and business world. Int. J. Forecast. 2009, 25, 794-812. [CrossRef]

37. Baum, T.; Hagen, L. Responses to seasonality: The experiences of peripheral destinations. Int. J. Tour. Res. 1999, 1, 299-312. [CrossRef]

38. Dorobăţ, M.L.; Dobrescu, C.M. The Anthropic Impact in the North-Western Side of Leaota Mountains. J. Curr. Trends Nat. Sci. 2016, 5, 63-72.

39. Foris, D.; Florescu, A.; Foris, T.; Barabas, S. Improving the Management of Tourist Destinations: A New Approach to Strategic Management at the DMO Level by Integrating Lean Techniques. Sustainability 2020, 12, 10201. [CrossRef]

40. Chu, F.-L. Forecasting tourism demand with ARMA-based methods. Tour. Manag. 2009, 30, 740-751. [CrossRef]

41. Alleyne, D. Can Seasonal Unit Root Testing Improve the Forecasting Accuracy of Tourist Arrivals? Tour. Econ. 2006, 12, 45-64. [CrossRef]

42. Paudel, T.; Dhakal, T.; Li, W.Y.; Kim, Y.G. A Macro Analysis of Tourist Arrival in Nepal. J. Asian Financ. Econ. Bus. 2021, 8, 207-215. [CrossRef]

43. Badulescu, A.; Simut, R.; Badulescu, D. The complex relationship between international tourism demand and economic growth: An analysis on Central and Eastern European economies. Amfiteatru Econ. 2018, 20, 935-950. [CrossRef]

44. Duro, J.A. Seasonality of hotel demand in the main Spanish provinces: Measurements and decomposition exercises. Tour. Manag. 2016, 52, 52-63. [CrossRef]

45. Cuccia, T.; Rizzo, I. Tourism seasonality in cultural destinations: Empirical evidence from Sicily. Tour. Manag. 2011, 32, 589-595. [CrossRef]

46. Sáez-Fernández, F.J.; Jiménez-Hernández, I.; Ostos-Rey, M.d.S. Seasonality and Efficiency of the Hotel Industry in the Balearic Islands: Implications for Economic and Environmental Sustainability. Sustainability 2020, 12, 3506. [CrossRef]

47. Li, G.; Song, H.; Witt, S.F. Recent Developments in Econometric Modelling and Forecasting. J. Travel Res. 2005, 44, 82-99. [CrossRef]

48. Turrión-Prat, J.; Duro, J.A. Seasonality determinants for the main markets in Spain. Int. J. Tour. Res. 2019, 21, 462-477. [CrossRef]

49. Çuhadar, M. Modelling and Forecasting Inbound Tourism Demand to Croatia using Artificial Neural Networks: A Comparative Study. J. Tour. Serv. 2020, 21, 55-70. [CrossRef]

50. Gunter, U.; Önder, I.; Smeral, E. Scientific value of econometric tourism demand studies. Ann. Tour. Res. 2019, 78, 102738. [CrossRef]

51. Kozak, M. Destination Benchmarking: Concepts, Practices and Operations; Kozak, M., Ed.; CABI: Wallingford, UK, 2004.

52. UN DESA. International Recommendations for Tourism Statistics 2008: Compilation Guide; Statistical Papers (Ser. M) No. 94; UN: New York, NY, USA, 2008; p. 295. [CrossRef]

53. Shu, M.; Hung, W. Forecasting with Fourier Residual Modified ARIMAvModel-An Empirical Case of Inbound Tourism Demand in New Zealand. WSEAS Trans. Math. 2014, 13, 12-21.

54. De Luca, G.; Rosciano, M. Quantile Dependence in Tourism Demand Time Series: Evidence in the Southern Italy Market. Sustain. 2020, 12, 3243. [CrossRef]

55. Schubert, S.F. COVID-19: Economic Consequences for a Small Tourism Dependent Economy. Revista Brasileira de Pesquisa em Turismo. Braz. J. Res. Tour. 2021, 15, 2297. [CrossRef]

56. Zambrano Farias, F.; Valls Martínez, M.d.C.; Martín-Cervantes, P.A. Explanatory Factors of Business Failure: Literature Review and Global Trends. Sustainability 2021, 13, 10154. [CrossRef] 
57. Xu, X.; Law, R.; Chen, W.; Tang, L. Forecasting tourism demand by extracting fuzzy Takagi-Sugeno rules from trained SVMs, CAAI. Trans. Intell. Technol. 2016, 1, 30-42. [CrossRef]

58. Jiao, E.X.; Chen, J.L. Tourism Forecasting: A Review of Methodological Developments over the Last Decade. Tour. Econ. 2019, 25, 469-492. [CrossRef]

59. Calantone, R.J.; Di Benedetto, C.A.; Bojanic, D. A Comprehensive Review Of The Tourism Forecasting Literature. J. Travel Res. 1987, 26, 28-39. [CrossRef]

60. Sheldon, P.J.; Var, T. Tourism forecasting: A review of empirical research. J. Forecast. 1985, 4, 183-195. [CrossRef]

61. Muzaffer, U.; Crompton, J.L. An Overview of Approaches Used to Forecast Tourism Demand. J. Travel Res. 1985, $23,7-15$. [CrossRef]

62. Kon, S.C.; Turner, L.W. Neural Network Forecasting of Tourism Demand. Tour. Econ. 2005, 11, 301-328. [CrossRef]

63. Oliveira Moreira, C.; Santos, N. Los Análisis Prospectivos Del Turismo: Construcción De Escenarios Mediante La Técnica Delphi. Cuad. Tur. 2020, 46, 423-457. [CrossRef]

64. Huang, Y.; Lee, Y. Accurately Forecasting Model for the Stochastic Volatility Data in Tourism Demand. Mod. Econ. 2011, 2, 823-829. [CrossRef]

65. Ghalehkhondabi, I.; Ardjmand, E.; Young, W.A.; Weckman, G.R. A review of demand forecasting models and methodological developments within tourism and passenger transportation industry. J. Tour. Futures 2019, 5, 75-93. [CrossRef]

66. $\mathrm{Hu}$, Y.-C. Developing grey prediction with Fourier series using genetic algorithms for tourism demand forecasting. Qual. Quant. Int. J. Methodol. 2021, 55, 315-331. [CrossRef]

67. Lee, C.-K.; Song, H.J.; Mjelde, J.W. The forecasting of International Expo tourism using quantitative and qualitative techniques. Tour. Manag. 2008, 29, 1084-1098. [CrossRef] [PubMed]

68. Chu, F.-L. A fractionally integrated autoregressive moving average approach to forecasting tourism demand. Tour. Manag. 2008, 29, 79-88. [CrossRef] [PubMed]

69. Martin, C.A.; Witt, S.F. Forecasting tourism demand: A comparison of the accuracy of several quantitative methods. Int. J. Forecast. 1989, 5, 7-19. [CrossRef]

70. Apergis, N.; Mervar, A.; Payne, J.E. Forecasting disaggregated tourist arrivals in Croatia: Evidence from seasonal univariate time series models. Tour. Econ. 2017, 23, 78-98. [CrossRef]

71. Karakitsiou, A.; Mavrommati, A. Machine learning methods in tourism demand forecasting: Some evidence from Greece. MIBES Trans. 2017, 11, 92-105.

72. Sun, S.; Wang, S.; Wei, Y.; Yang, X.; Tsui, K.-L. Forecasting tourist arrivals with machine learning and internet search index. In Proceedings of IEEE International Conference on Big Data (Big Data), Boston, MA, USA, 11-14 December 2017.

73. Bi, J.-W.; Han, T.-Y.; Li, H. International tourism demand forecasting with machine learning models: The power of the number of lagged inputs. Tour. Econ. 2020, 16, 153-168. [CrossRef]

74. Birim, S.; Kazancoglu, I.; Mangla, S.K.; Kahraman, A.; Kazancoglu, Y. The derived demand for advertising expenses and implications on sustainability: A comparative study using deep learning and traditional machine learning methods. Ann. Oper. Res. 2022. [CrossRef]

75. Claveria, O.; Monte, E.; Torra, S. Combination forecasts of tourism demand with machine learning models. Appl. Econ. Lett. 2016, 23, 428-431. [CrossRef]

76. Palmer, A.; Montaño, J.J.; Sesé, A. Designing an artificial neural network for forecasting tourism time series. Tour. Manag. 2006, 27, 781-790. [CrossRef]

77. Teixeira, J.P.; Fernandes, P.O. Tourism time series forecast with artificial neural networks. Tékhne 2014, 12, 26-36. [CrossRef]

78. Shabri, A.; Samsudin, R.; Yusoff, Y. Combining Deep Neural Network and Fourier Series for Tourist Arrivals Forecasting. In Proceedings of the IOP Conference Series: Materials Science and Engineering, Proceedings of 2nd Joint Conference on Green Engineering Technology \& Applied Computing, Bangkok, Thailand, 4-5 February 2020.

79. Nguyen, L.Q.; Fernandes, P.O.; Teixeira, J.P. Analyzing and Forecasting Tourism Demand in Vietnam with Artificial Neural Networks. Forecasting 2022, 4, 36-50. [CrossRef]

80. Song, H.; Lin, S.; Zhang, X.; Gao, Z. Global Financial/Economic Crisis and Tourist Arrival Forecasts for Hong Kong. Asia Pac. J. Tour. Res. 2010, 15, 223-242. [CrossRef]

81. Ongan, S.; Gozgor, G. Tourism demand analysis: The impact of the economic policy uncertainty on the arrival of Japanese tourists to the USA. Int. J. Tour. Res. 2018, 20, 308-316. [CrossRef]

82. Cortes-Jimenez, I.; Blake, A. Tourism Demand Modeling by Purpose of Visit and Nationality. J. Travel Res. 2011, 50, 408-416. [CrossRef]

83. Zhang, H.; Song, H.; Wen, L.; Liu, C. Forecasting tourism recovery amid COVID-19. Ann. Tour. Res. 2021, 87, 103149. [CrossRef]

84. Goumas, S.K.; Kontakos, S.; Mathheaki, A.G.; Xristoforidis, S. Modeling and Forecasting of Tourist Arrivals in Crete Using Statistical Models and Models of Computational Intelligence: A Comparative Study. Int. J. Oper. Res. Inf. Syst. (IJORIS) 2012, 12, 58-72. [CrossRef]

85. Önder, I. Forecasting tourism demand with Google Trends: Accuracy comparison of countries versus cities. Int. J. Tour. Res. 2017, 19, 648-660. [CrossRef]

86. Marques Santos, A.; Madrid, C.; Haegeman, K.; Rainoldi, A. Behavioural Changes in Tourism in Times of COVID-19; Publications Office of the European Union: Luxembourg, 2020. [CrossRef] 
87. Gujarati, D. Basic Econometric 4; McGraw-Hill Companies, Inc.: New York, NY, USA, 2004.

88. Killick, R.; Knight, M.I.; Nason, G.P.; Eckley, I.A. The local partial autocorrelation function and some applications. Electron. J. Statist. 2020, 14, 3268-3314. [CrossRef]

89. Islam, M.; Akhtar, A.; Munira, S.; Khan, M.S.; Murshed, M.M. Optimized Dickey-Fuller Test Refines Sign and Boundary Problems Compare to Traditional Dickey-Fuller Test. Int. J. Stat. Probab. 2018, 7, 19-27. [CrossRef]

90. Vogelsang, T.; Wagner, M. A fixed-b perspective on the Phillips-Perron Unit Root Tests. Econom. Theory 2013, 29, 609-628. [CrossRef]

91. Hietikko, H. On the numerical behaviour of $\mathrm{ARMA}(\mathrm{P}, \mathrm{Q})$ covariance determinants for various sample sizes. Commun. Stat.-Simul. Comput. 1981, 10, 451-463. [CrossRef] 